AperTO - Archivio Istituzionale Open Access dell'Università di Torino

\title{
Hyperaldosteronism: How to Discriminate Among Different Disease Forms?
}

\section{This is a pre print version of the following article:}

Original Citation:

Availability:

This version is available http://hdl.handle.net/2318/1621327

since 2018-09-19T12:50:39Z

Published version:

DOI:10.1007/s40292-016-0151-6

Terms of use:

Open Access

Anyone can freely access the full text of works made available as "Open Access". Works made available under a Creative Commons license can be used according to the terms and conditions of said license. Use of all other works requires consent of the right holder (author or publisher) if not exempted from copyright protection by the applicable law. 
Hyperaldosteronism: how to discriminate among different disease forms?

Valentina Crudo, Silvia Monticone, Jacopo Burrello, Fabrizio Buffolo, Martina Tetti, Franco Veglio, Paolo Mulatero.

$\underline{\text { Affiliations }}$

Division of Internal Medicine and Hypertension, Department of Medical Sciences, University of Torino, 10126 Torino, Italy

Short title: subtype diagnosis of primary aldosteronism

Key words: primary aldosteronism, aldosterone producing adenoma, adrenal vein sampling, secondary hypertension

Corresponding author: Paolo Mulatero, Division of Internal Medicine and Hypertension, Department of Medical Sciences, University of Torino, Via Genova 3, 10126, Torino, Italy. e-mail: paolo.mulatero@unito.it fax:-39-011-6336931; ph:-39-011-6336959

Authors disclosure/conflict of interest: the authors have nothing to disclose Source of Funding: None

Word count: abstract: 112; manuscript: 2221 (excluded references and tables); number of tables: 2. 


\section{Abstract}

2 Primary aldosteronism (PA), characterized by the inappropriate and excessive

3 adrenal secretion of aldosterone, is the most common cause of secondary

4 hypertension; PA has been shown to increase cardio- and cerebro-vascular risks

5 in comparison with essential hypertension. PA is a multi-faceted disease, which

6 comprises unilateral forms, benefitting from surgical treatment, and bilateral

7 forms, which are best managed medically; PA is more frequently sporadic but in

8 some cases displays a familial transmission pattern. For these reasons, it is

9 important to diagnose PA early on and correctly distinguish and manage its

10 different forms.

11 In this review, we analyze the different forms of PA, with attention on the 12 diagnostic pathway and the genetics of the disease.

13 
Introduction

2 Primary aldosteronism (PA) is defined as a syndrome, characterized by an

3 inappropriate secretion of aldosterone, independent of the renin-angiotensin

4 system and of sodium homeostasis. PA prevalence increases with blood pressure

5 severity reaching up to $20 \%$ in patients with resistant hypertension [1,2]. Recent

6 studies have also uncovered wider effects of aldosterone that go beyond BP, and

7 affect a number of different target organs, in particular determining higher cardio-

8 and cerebro-vascular risks in PA patients as compared to essential hypertensives

9 with a similar risk profile $[3,4]$.

10 Therefore, early detection of PA, is fundamental to best manage short and long-

11 term complications of this condition.

12 The two most common forms of PA are the aldosterone-producing adenoma 13 (APA), which accounts for $30-35 \%$ of all cases, and the bilateral adrenal 14 hyperplasia (BAH), the most common PA subtype accounting for $65-70 \%$ of PA 15 patients [5]. The therapeutic approaches are different depending from the 16 subtypes, surgical for unilateral PA forms and medical treatment with 17 mineralocorticoid receptors (MR) antagonists for BAH [5]. It should be noted that 18 a relevant proportion of patients with unilateral PA, previously considered affectd 19 by APA, display a moltinodular unilateral adrenal hyperplasia with one or more 20 nodules expressing CYP11B2 with immunohistochemistry evaluation [6,7].

21 These two forms of PA, both sporadic, together comprise the vast majority of all 22 PA cases; less common, but nonetheless important in the diagnostic pathway, are 23 the four familial forms. Recognition of these is important not only in the treatment 24 of patient, but also in the screening of first-grade family members. 
1 In this manuscript we will review the subtype diagnosis of sporadic and familial

2 PA.

4 Diagnosis

5 Diagnosis of PA is made by a screening test using the aldosterone to renin (or

6 plasma renin activity ratio) [5]. Population with increased risk of PA that should

7 be screened and the relationships and characteristics of different aldosterone and

8 renin assay are described elsewhere [8-10]. Confirmation of the suspicion of PA

9 is made by one of four confirmatory/exclusion tests: the intravenous saline

10 loading test, the oral saline loading test, the fludrocortisone-suppression test and

11 the captopril challenge test. Characteristics and performance of the different 12 confirmatory tests are discussed elsewhere [5,11].

\section{Imaging techniques and steroid measurements}

15 Once PA is confirmed, patients should undergo contrast-enhanced computed 16 tomography (CT) scanning evaluation of the adrenal glands $[5,12]$ as a first exam.

17 CT findings can vary, from bilateral hyperplasia, to unilateral hyperplasia, to 18 unilateral or bilateral micro and macro-nodules (diameter $<1 \mathrm{~cm}$ or $>1 \mathrm{~cm}$ ).

19 Lesions bigger than $4 \mathrm{~cm}$ are suspicious for the rare but deadly adrenal carcinoma

20 [5]. CT displays several limitations: even using fine-cuts, CT may fail at identifying 21 micro-APAs; moreover, it does not provide information on the functional role of 22 the nodules, which can be especially crucial when bilateral lesions are observed $23[13]$. 
1 Other imaging techniques are available: the Endocrine Society approves magnetic

2 resonance as an alternative to contrast CT, though it admittedly provides a lower

3 quality of space resolution, and lower specificity [5].

4 Among functional imaging, ${ }^{131}$ I-6 6 -iodomethyl-19-norcholesterol scintiscan has

5 been abandoned; a more recent technique is the ${ }^{11} \mathrm{C}$-metomidate positron

6 emission tomography (PET)-CT scan, that could be considered an alternative to

7 AVS when this is unsuccessful, but that display a lower sensitivity and specificity

8 that makes it not suitable to substitute AVS routinely [14]. One of the limits of

9 metomidate is its low selectivity for CYP11B1 over CYP11B2. For this reason, a

10 Japanese group has tested a new, more CYP11B2-specific tracer, ${ }^{18 F-C D P 2230 . ~}$

11 However, this new technique needs to be tested in a prospective trial in 12 comparison with AVS [15].

13 An additional instrument in the diagnosis of APA versus BAH has been suggested 14 with the measurement of the so-called "hybrid" steroids 18-oxocortisol (18oxoF) 15 and 18-hydroxycortisol (180HF), that are produced in large amount in a 16 consistent proportion of APA compared to BAH and incidentalomas [16,17]. 17 Recently, through a more complete steroid profiling using liquid chromatography 18 - tandem mass spectrometry (LC-MS/MS) to simultaneously measure 7 different 19 adrenal steroids, it was possible to distinguish APA from BAH in a consistent 20 proportion of cases and to identify those APA with a specific somatic genetic 21 alteration $[18,19]$. If this results will be confirmed in large prospective studies, 22 steroid profiling by LC-MS/MS promise to be a preliminary test in order to identify 23 PA patients with high probability of unilateral PA, thus reducing significantly the 24 requirement for AVS procedures. 


\section{Adrenal venous sampling}

2 Adrenal venous sampling, or AVS, is widely recognized as the gold standard

3 technique in the distinction of unilateral from bilateral PA $[5,12]$. In a review of

4950 cases, imaging technique (either CT scanning or magnetic resomnance)

5 resulted in a wrong diagnosis in around 38\% of cases compared to AVS [20]. CT

6 scanning can suggest inappropriate adrenalectomy in patients with BAH and

7 unilateral nodule, or miss the opportunity of cure by adrenalectomy in cases of

8 unilateral PA and bilateral nodules (with only one having secretory activity) or

9 normal appearing adrenals and undetected micro-APA $[5,20]$. The main pitfall of

10 CT scanning is the lack of a proper identification of secretory activity of detected

11 nodules; different parameters have been suggested, such as densitometry and

12 contrast wash-out, but neither has been proven to provide definite answers in the

13 distinction between secreting lesions and incidentalomas [5,21]. Therefore, when

14 adrenalectomy is not contraindicated because of comorbidities, AVS should

15 always be suggested as the only reliable technique for PA subtype diagnosis $16[5,22]$.

17 AVS is a complicated procedure, which not only requires an expert operator, but 18 also an adequate preparation of the patient. In the 4-6 weeks leading to the 19 procedure, it is suggested to treat hypertension with alpha-blockers and non20 dyhidropyridine calcium channel blockers, as they display the least influence on

21 the renin-angiotensin system; if these drugs are not sufficient to reach the desired

22 blood pressure control, beta-blockers, ACE-inhibitors and angiotensin-receptors 23 blockers can be considered, while drugs such as thiazides, loop diuretics, 24 amiloride and mineralocorticoid receptors antagonists should be avoided since 25 they affect AVS results and interpretation. Potassium levels should be kept within 
1 normal range [22]. AVS can be performed both under basal or during cosyntropin

2 infusion with similar results [23]. Pro and cons of the two procedures are

3 described elsewhere [22].

4 During AVS a catheter is inserted percutaneously in a femoral vein and, through

5 the use of contrast medium and fluoroscopy, the adrenal veins are singled out, and

6 blood is gently drawn. Procedure techniques can be challenging, and an expert

7 operator is required, as success rates can vary between $44 \%$ and $96 \%$, according

8 to the radiologist expertise $[22,24,25]$.

9 Left adrenal vein cannulation is relatively easy, as the vein joins the inferior

10 phrenic vein to create a common vessel that drains into the left renal vein. Right

11 adrenal vein, on the other hand, creates a very sharp angle in its emergency

12 directly into the inferior vena cava, which can be challenging to cannulate even for

13 an expert radiologist [24,25]. To avoid potential errors determined by blood

14 dilution during adrenal veins cannulations, aldosterone values are always

15 "corrected" by cortisol since it is considered that this hormone is equally produced

16 from the two adrenals in PA patients [5,22].

17 Cortisol measurement is also used to determine the correct cannulation of the

18 adrenal veins. The two most important parameters measured during AVS are are

19 the selectivity index (SI), which is the ratio between cortisol in the adrenal vein

20 and cortisol in a peripheral vein (Table 1): this provides information about the

21 adequacy of cannulation of the adrenal vein; and the lateralization index (LI)

22 which determine the presence or not of a lateralization of aldosterone secretion.

23 It is calculated as the ratio between cortisol-corrected aldosterone levels in one

24 adrenal compare to the contralateral. A result of $\mathrm{LI}>4$ is diagnostic for unilateral 
1 PA (Table 1). A LI $<3$ is diagnostic for BAH. For LI between 3 and 4 other clinical

2 parameters should be taken into account for final decision $[5,21,26]$.

3 Another AVS parameter is the contralateral ration, that is the cortisol-corrected

4 aldosterone ratio from the non-dominant adrenal vein in comparison with the

5 peripheral vein (Table 1). A recent study has demonstrated that a contralateral

6 suppression (i.e. a contralateral ratio $<1$ ) is not necessary to obtain cure or

7 significant improvement of blood pressure levels after adrenalectomy [27].

8 AVS requires an experienced radiologist with an expertise in endovascular

9 procedures, in order to minimize risks, most commonly the rupture of an adrenal

10 vein during the procedure. The multi-centric study AVIS showed an inverse

11 correlation between the experience of the radiologist and numbers of procedures

12 done and the chance of complications [28]. The most serious complication of AVS

13 is adrenal hemorrhage. A retrospective study analyzed 24 cases of adrenal

14 hemorrhage in patients who underwent AVS in 6 different referral centers; of

15 these, the majority involved the right adrenal, coherent with the difficulty in the

16 right adrenal vein cannulation and were more frequent in older patients [29].

17 Interestingly, among all the analyzed cases, only one needed long-term

18 corticosteroid replacement therapy for adrenal insufficiency. All hemorrhages

19 were minor, and controlled by medical therapy without the need for new surgery

20 or blood transfusions [29].

22 Genetics of PA

23 Familial hyperaldosteronism (FH) account for up to 5-6\% of all PA cases [30,31].

24 The first form of FH to be discovered is also named glucocortidoid-remediable

25 aldosteronism (GRA, or FH-I), which is caused by the creation of a chimeric gene 
1 from the fusion of the promoter region of the 11ß-hydroxylase gene CYP11B1 with

2 the coding region of the aldosterone synthase gene, CYP11B2 [32,33] (Table 2).

3 This determines a regulation of aldosterone production under the very active

4 CYP11B1 (encoding 11 $\beta$-hydroxylase) promoter, which is regulated by ACTH.

5 Patients with GRA usually present hypertension in the first two decades of their

6 lives, and an increased risk of cerebral hemorrhage; moreover they show high

7 levels of hybrid steroids. Transmission is autosomal dominant, and the disease,

8 once diagnosed, can be easily managed by administration of low doses of

9 glucocorticoids, often associated with mineralocorticoid receptor blockers [34].

10 FH-II is clinically undistinguishable from sporadic PA, and it is diagnosed by the

11 familial pattern of the disease. Its genetics basis is still unknown, though a linkage

12 to chromosome 7 p22 has been suggested [35,36]. It is conceivable that more

13 types of genetic alterations are responsible for this condition (Table 2).

14 FH-III is has been recently described by Choi in 2011 [37]. This disease is 15 characterized more frequently by very early onset of severe hypertension and 16 hyperaldosteronism that require bilateral adrenalectomy in most cases. FH-III is 17 determined by gain-of-function mutations of KCNJ5 which KCNJ5 encodes for the 18 potassium inwardly-rectifying channel Kir 3.4 [34] (Table 2); the mutations cause 19 the channel to lose its selectivity for potassium, allowing large quantities of 20 sodium to enter the cell, thus causing a membrane depolarization and the 21 activation of voltage-gated calcium channels, with calcium influx into the cell, and 22 activation of the cascade that results in aldosterone overproduction [38]. It should 23 be noted, that cases with more mild phenotypes have been described $[34,39,40]$.

24 Primary aldosteronism with seizures and neurological abnormalities (PASNA) is 25 an extremely severe form of PA, caused by a germline mutation in CACNA1D, which 
1 encodes a voltage-gated L-type calcium channel (Table 2); the mutations result in

2 channel activation at less depolarized potentials, which in turn causes calcium

3 influx and aldosterone production [41,42]. Only two cases have been diagnosed

4 so far: both patients were diagnosed at a very young age from healthy parents; it

5 is believed that their neurological impairment is so severe not to allow affected

6 individuals to reproduce. Therefore, this condition is considered not-familial

7 despite the genetic cause and is expected to be caused only by de novo mutations.

8 The latest discovery in familial forms is FH-IV, described by Scholl et al. in 2015

9 [43]: FH-IV is caused by a germline mutation in another voltage-gated calcium

10 channel gene, CACNA1H, highly expressed in the zona glomerulosa (Table 2). All

11 index cases had PA and severe hypertension diagnosed by the age of 10 years, but

12 without neurological abnormalities. Inheritance of FH-IV is autosomal dominant,

13 though with incomplete penetrance, as carrier parents did not show the same

14 severe hypertension as the index cases [44] and also normotensive individuals

15 with the mutation were observed.

16 Intriguingly, mutations in KCNJ5 and CACNA1D were also described as somatic 17 mutations in sporadic APAs [42,45]. Other somatic mutations in genes 18 responsible for aldosterone overproduction (ATP1A1 and ATP2B3) or involved in 19 cell proliferation (CTNNB1) have also been described but without evidence of 20 similar alterations responsible for familial forms [46,47].

21 PA patients with APA carrying mutations display in some cases specific steroid 22 profiles that may help clinicians in the decision making process of PA subtype 23 diagnosis [18]. 
1 Genetic basis for sporadic BAH are less understood for the difficulty of studying

2 adrenal glands from this patients. In some cases, KCNJ5 mutations have been

3 described, not associated to FH-III [48].

4 Heterozygous germline mutations in the armadillo repeat containing 5 gene 5 (ARMC5) have been shown in patients with hypercortisolism due to sporadic

6 primary bilateral macronodular adrenal hyperplasia [49] and were also described

7 in observed in African-American PA patients [50] but not in a cohort of Caucasian

8 BAH patients [51].

9

\section{Conclusions}

11 PA is a multi-faceted disease, which can lead to severe cardio- and cerebro12 vascular complications in affected patients. Different subtypes of disease benefit

13 from different treatment options, and should therefore be carefully distinguished, 14 in order to ensure the best management for the patients.

\section{Bibliography}

17 1. Mosso L, Carvajal C, González A, Barraza A, Avila F, Montero J, Huete A,

18 Gederlini A, Fardella C. Primary aldosteronism and hypertensive disease.

19 Hypertension 2003;42:161-5.

20 2. Calhoun DA, Nishizaka MK, Zaman MA, Thakkar RB, Weissmann P.

21 Hyperaldosteronism among black and white subjects with resistant

22 hypertension. Hypertension 2002;40:892-6.

23 3. Savard S, Amar L, Plouin PF, Steichen O. Cardiovascular complications

24 associated with primary aldosteronism: A controlled cross-sectional study.

25 Hypertension 2013;62:331-6. 
1 4. Mulatero P, Monticone S, Bertello C, Viola A, Tizzani D, Iannaccone A, Crudo V,

2 Burrello J, Milan A, Rabbia F, Veglio F. Long-term cardio- and cerebrovascular

3 events in patients with primary aldosteronism. J Clin Endocrinol Metab

$4 \quad 2013 ; 98: 4826-33$.

5 5. Funder JW, Carey RM, Fardella C, Gomez-Sanchez CE, Mantero F, Stowasser M,

6 Young WF, Montori VM. Case detection, diagnosis, and treatment of patients with

7 primary aldosteronism: An endocrine society clinical practice guideline. The

8 Journal of Clinical Endocrinology \& Metabolism 2008;93:3266-81.

9 6. Dekkers T, ter Meer M, Lenders JW, Hermus AR, Schultze Kool L,

10 Langenhuijsen JF, Nishimoto K, Ogishima T, Mukai K, Azizan EAB, Tops B,

11 Deinum J, Küsters B. Adrenal nodularity and somatic mutations in primary

12 aldosteronism: One node is the culprit? J Clin Endocrinol Metab 2014;99:E1341-

1351.

14 7. Monticone S, Castellano I, Versace K, Lucatello B, Veglio F, Gomez-Sanchez CE,

15 Williams TA, Mulatero P. Immunohistochemical, genetic and clinical

16 characterization of sporadic aldosterone-producing adenomas. Mol Cell

17 Endocrinol 2015;411:146-54.

18 8. Monticone S, Viola A, Tizzani D, Crudo V, Burrello J, Galmozzi M, Veglio F,

19 Mulatero P. Primary aldosteronism: Who should be screened? Horm Metab Res

$20 \quad 2012 ; 44: 163-9$.

21 9. Burrello J, Monticone S, Buffolo F, Lucchiari M, Tetti M, Rabbia F, Mengozzi G,

22 Williams TA, Veglio F, Mulatero P. Diagnostic accuracy of aldosterone and renin

23 measurement by chemiluminescent immunoassay and radioimmunoassay in

24 primary aldosteronism. J Hypertens 2016; Epub ahead of print. 
1 10. Manolopoulou J, Fischer E, Dietz A, Diederich S, Holmes D, Junnila R,

2 Grimminger P, Reincke M, Morganti A, Bidlingmaier M. Clinical validation for the

3 aldosterone-to-renin ratio and aldosterone suppression testing using

4 simultaneous fully automated chemiluminescence immunoassays. J Hypertens

$5 \quad 2015 ; 33: 2500-11$.

6 11. Mulatero P, Monticone S, Bertello C, Mengozzi G, Tizzani D, Iannaccone A,

7 Veglio F. Confirmatory tests in the diagnosis of primary aldosteronism. Horm

$8 \quad$ Metab Res 2010;42:406-10.

9 12. Nishikawa T, Omura M, Satoh F, Shibata H, Takahashi K, Tamura N, Tanabe A.

10 Guidelines for the diagnosis and treatment of primary aldosteronism-the japan

11 endocrine society 2009. Endocrine Journal 2011;58:711-21.

12 13. Patel SM, Lingam RK, Beaconsfield TI, Tran TL, Brown B. Role of radiology in

13 the management of primary aldosteronism. Radiographics 2007;27:1145-57.

14 14. Burton TJ, Mackenzie IS, Balan K, Koo B, Bird N, Soloviev DV, Azizan EAB,

15 Aigbirhio F, Gurnell M, Brown MJ. Evaluation of the sensitivity and specificity of

16 (11)c-metomidate positron emission tomography (PET)-CT for lateralizing

17 aldosterone secretion by conn's adenomas. J Clin Endocrinol Metab

$18 \quad 2012 ; 97: 100-9$.

19 15. Abe T, Naruse M, Young WF, Kobashi N, Doi Y, Izawa A, Akama K, Okumura Y,

20 Ikenaga M, Kimura H, Saji H, Mukai K, Matsumoto H. A novel cyp11b2-specific

21 imaging agent for detection of unilateral subtypes of primary aldosteronism. J

22 Clin Endocrinol Metab 2016;jc20153431.

23 16. Satoh F, Morimoto R, Ono Y, Iwakura Y, Omata K, Kudo M, Takase K, Seiji K,

24 Sasamoto H, Honma S, Okuyama M, Yamashita K, Gomez-Sanchez CE, Rainey WE,

25 Arai Y, Sasano H, Nakamura Y, Ito S. Measurement of peripheral plasma 18- 
1 oxocortisol can discriminate unilateral adenoma from bilateral diseases in

2 patients with primary aldosteronism. Hypertension 2015;65:1096-102.

3 17. Mulatero P, di Cella SM, Monticone S, Schiavone D, Manzo M, Mengozzi G,

4 Rabbia F, Terzolo M, Gomez-Sanchez EP, Gomez-Sanchez CE, Veglio F. 18-

5 hydroxycorticosterone, 18-hydroxycortisol, and 18-oxocortisol in the diagnosis

6 of primary aldosteronism and its subtypes. J Clin Endocrinol Metab 2012;97:881-

79.

8 18. Williams TA, Peitzsch M, Dietz AS, Dekkers T, Bidlingmaier M, Riester A,

9 Treitl M, Rhayem Y, Beuschlein F, Lenders JWM, Deinum J, Eisenhofer G, Reincke

10 M. Genotype-Specific steroid profiles associated with aldosterone-producing

11 adenomas. Hypertension 2016;67:139-45.

12 19. Eisenhofer G, Dekkers T, Peitzsch M, Dietz AS, Bidlingmaier M, Treitl M,

13 Williams TA, Bornstein SR, Haase M, Rump LC, Willenberg HS, Beuschlein F,

14 Deinum J, Lenders JWM, Reincke M. Mass spectrometry--based adrenal and

15 peripheral venous steroid profiling for subtyping primary aldosteronism. Clinical

16 Chemistry 2016; clinchem-2015.

17 20. Kempers MJ, Lenders JW, van Outheusden L, van der Wilt GJ, Schultze Kool LJ,

18 Hermus AdRMM, Deinum J. Systematic review: Diagnostic procedures to

19 differentiate unilateral from bilateral adrenal abnormality in primary

20 aldosteronism. Ann Intern Med 2009;151:329-37.

21 21. Blake MA, Cronin CG, Boland GW. Adrenal imaging. AJR Am J Roentgenol

$22 \quad 2010 ; 194: 1450-60$.

23 22. Monticone S, Viola A, Rossato D, Veglio F, Reincke M, Gomez-Sanchez CE,

24 Mulatero P. Adrenal vein sampling in primary aldosteronism: Towards a

25 standardised protocol. Lancet Diabetes Endocrinol 2015;3:296-303. 
1 23. Monticone S, Satoh F, Giacchetti G, Viola A, Morimoto R, Kudo M, Ikawura Y,

2 Ono Y, Turchi F, Paci E, Veglio F, Boscaro M, Rainey WE, Ito S, Mulatero P. Effect

3 of adrenocorticotropic hormone stimulation during adrenal vein sampling in

4 primary aldosteronism. Hypertension 2012;59:840-6.

5 24. Young WF. Primary aldosteronism: Renaissance of a syndrome. Clin

6 Endocrinol (Oxf) 2007;66:607-18.

7 25. Daunt N. Adrenal vein sampling: How to make it quick, easy, and successful.

$8 \quad$ Radiographics 2005;25 Suppl 1:S143-58.

9 26. Burrello J, Monticone S, Tetti M, Rossato D, Versace K, Castellano I, Williams

10 TA, Veglio F, Mulatero P. Subtype diagnosis of primary aldosteronism: Approach

11 to different clinical scenarios. Horm Metab Res 2015;47:959-66.

12 27. Monticone S, Satoh F, Viola A, Fischer E, Vonend O, Bernini G, Lucatello B,

13 Quinkler M, Ronconi V, Morimoto R, Kudo M, Degenhart C, Gao X, Carrara D,

14 Willenberg HS, Rossato D, Mengozzi G, Riester A, Paci E, Iwakura Y, Burrello J,

15 Maccario M, Giacchetti G, Veglio F, Ito S, Reincke M, Mulatero P. Aldosterone

16 suppression on contralateral adrenal during adrenal vein sampling does not

17 predict blood pressure response after adrenalectomy. J Clin Endocrinol Metab

$18 \quad 2014 ; 99: 4158-66$.

19 28. Rossi GP, Barisa M, Allolio B, Auchus RJ, Amar L, Cohen D, Degenhart C,

20 Deinum J, Fischer E, Gordon R, Kickuth R, Kline G, Lacroix A, Magill S, Miotto D,

21 Naruse M, Nishikawa T, Omura M, Pimenta E, Plouin PF, Quinkler M, Reincke M,

22 Rossi E, Rump LC, Satoh F, Schultze Kool L, Seccia TM, Stowasser M, Tanabe A,

23 Trerotola S, Vonend O, Widimsky J, Wu KD, Wu VC, Pessina AC. The adrenal vein

24 sampling international study (AVIS) for identifying the major subtypes of

25 primary aldosteronism. J Clin Endocrinol Metab 2012;97:1606-14. 
1 29. Monticone S, Satoh F, Dietz AS, Goupil R, Lang K, Pizzolo F, Gordon RD,

2 Morimoto R, Reincke M, Stowasser M, Mulatero P. Clinical management and

3 outcomes of adrenal hemorrhage following adrenal vein sampling in primary

4 aldosteronism. Hypertension 2016;67:146-52.

5 30. Stowasser M, Pimenta E, Gordon RD. Familial or genetic primary

6 aldosteronism and gordon syndrome. Endocrinol Metab Clin North Am

$7 \quad 2011 ; 40: 343-68$, viii.

8 31. Mulatero P, Tizzani D, Viola A, Bertello C, Monticone S, Mengozzi G, Schiavone

9 D, Williams TA, Einaudi S, La Grotta A, Rabbia F, Veglio F. Prevalence and

10 characteristics of familial hyperaldosteronism: The PATOGEN study (primary

11 aldosteronism in torino-genetic forms). Hypertension 2011;58:797-803.

12 32. Sutherland DJ, Ruse JL, Laidlaw JC. Hypertension, increased aldosterone

13 secretion and low plasma renin activity relieved by dexamethasone. Can Med

14 Assoc J 1966;95:1109-19.

15 33. Lifton RP, Dluhy RG, Powers M, Rich GM, Cook S, Ulick S, Lalouel JM. A

16 chimaeric 11 beta-hydroxylase/aldosterone synthase gene causes

17 glucocorticoid-remediable aldosteronism and human hypertension. Nature

$18 \quad 1992 ; 355: 262-5$.

19 34. Mulatero P, Monticone S, Rainey WE, Veglio F, Williams TA. Role of KCNJ5 in

20 familial and sporadic primary aldosteronism. Nat Rev Endocrinol 2013;9:104-12.

21 35. Carss KJ, Stowasser M, Gordon RD, O'Shaughnessy KM. Further study of

22 chromosome 7p22 to identify the molecular basis of familial hyperaldosteronism

23 type II. J Hum Hypertens 2011;25:560-4.

24 36. Sukor N, Mulatero P, Gordon RD, So A, Duffy D, Bertello C, Kelemen L, Jeske Y

25 Veglio F, Stowasser M. Further evidence for linkage of familial 
1 hyperaldosteronism type II at chromosome 7p22 in italian as well as australian

2 and south american families. J Hypertens 2008;26:1577-82.

3 37. Choi M, Scholl UI, Yue P, Björklund P, Zhao B, Nelson-Williams C, Ji W, Cho Y,

4 Patel A, Men CJ, Lolis E, Wisgerhof MV, Gellder DS, Mane S, Hellman P, Westin G,

5 Åkerström G, Wang W, Carling T, Lifton RP. K+ channel mutations in adrenal

6 aldosterone-producing adenomas and hereditary hypertension. Science

$7 \quad 2011 ; 331: 768-72$.

8 38. Williams TA, Monticone S, Crudo V, Warth R, Veglio F, Mulatero P. Visinin-like

91 is upregulated in aldosterone-producing adenomas with KCNJ5 mutations and

10 protects from calcium-induced apoptosis. Hypertension 2012;59:833-9.

11 39. Monticone S, Hattangady NG, Penton D, Isales CM, Edwards MA, Williams TA,

12 Sterner C, Warth R, Mulatero P, Rainey WE. A novel Y152C KCNJ5 mutation

13 responsible for familial hyperaldosteronism type III. J Clin Endocrinol Metab

$14 \quad$ 2013;98:E1861-5.

15 40. Monticone S, Bandulik S, Stindl J, Zilbermint M, Dedov I, Mulatero P, Allgaeuer

16 M, Lee CCR, Stratakis CA, Williams TA. A case of severe hyperaldosteronism

17 caused by a de novo mutation affecting a critical salt bridge kir3. 4 residue. The

18 Journal of Clinical Endocrinology \& Metabolism 2014;100:E114-8.

19 41. Scholl UI, Goh G, Stölting G, de Oliveira RC, Choi M, Overton JD, Fonseca AL,

20 Korah R, Starker LF, Kunstman JW. Somatic and germline CACNA1D calcium

21 channel mutations in aldosterone-producing adenomas and primary

22 aldosteronism. Nat Genet 2013;45:1050-4.

23 42. Monticone S, Else T, Mulatero P, Williams TA, Rainey WE. Understanding

24 primary aldosteronism: Impact of next generation sequencing and expression

25 profiling. Mol Cell Endocrinol 2015;399:311-20. 
1 43. Scholl UI, Stölting G, Nelson-Williams C, Vichot AA, Choi M, Loring E, Prasad

2 ML, Goh G, Carling T, Juhlin CC, Quack I, Rump LC, Thiel A, Lande M, Frazier BG,

3 Rasoulpour M, Bowlin DL, Sethna CB, Trachtman H, Fahlke C, Lifton RP.

4 Recurrent gain of function mutation in calcium channel CACNA1H causes early-

$5 \quad$ onset hypertension with primary aldosteronism. Elife 2015;4:e06315.

6 44. Korah HE, Scholl UI. An update on familial hyperaldosteronism. Hormone and

$7 \quad$ Metabolic Research 2015;47:941-6.

8 45. Williams TA, Lenders JW, Burrello J, Beuschlein F, Reincke M. KCNJ5

9 mutations: Sex, salt and selection. Horm Metab Res 2015;47:953-8.

10 46. Beuschlein F, Boulkroun S, Osswald A, Wieland T, Nielsen HN, Lichtenauer

11 UD, Penton D, Schack VR, Amar L, Fischer E. Somatic mutations in ATP1A1 and

12 ATP2B3 lead to aldosterone-producing adenomas and secondary hypertension.

13 Nat Genet 2013;45:440-4.

14 47. Åkerström T, Maharjan R, Sven Willenberg H, Cupisti K, Ip J, Moser A,

15 Stålberg P, Robinson B, Iwen KA, Dralle H, Walz MK, Lehnert H, Sidhu S, Gomez-

16 Sanchez CE, Hellman P, Björklund P. Activating mutations in CTNNB1 in

17 aldosterone producing adenomas. Sci Rep 2016;6:19546.

18 48. Murthy M, Xu S, Massimo G, Wolley M, Gordon RD, Stowasser M,

19 O'Shaughnessy KM. Role for germline mutations and a rare coding single

20 nucleotide polymorphism within the KCNJ5 potassium channel in a large cohort

21 of sporadic cases of primary aldosteronism. Hypertension 2014;63:783-9.

22 49. Assié G, Libé R, Espiard S, Rizk-Rabin M, Guimier A, Luscap W, Barreau O,

23 Lefèvre L, Sibony M, Guignat L. ARMC5 mutations in macronodular adrenal

24 hyperplasia with cushing's syndrome. New England Journal of Medicine

$25 \quad 2013 ; 369: 2105-14$. 
1 50. Zilbermint M, Xekouki P, Faucz FR, Berthon A, Gkourogianni A, Schernthaner-

2 Reiter MH, Batsis M, Sinaii N, Quezado MM, Merino M, Hodes A, Abraham SB, Libé

3 R, Assié G, Espiard S, Drougat L, Ragazzon B, Davis A, Gebreab SY, Neff R,

4 Kebebew E, Bertherat J, Lodish MB, Stratakis CA. Primary aldosteronism and

5 ARMC5 variants. J Clin Endocrinol Metab 2015;100:E900-9.

6 51. Mulatero P, Schiavi F, Williams TA, Monticone S, Barbon G, Opocher G, Fallo F.

7 ARMC5 mutation analysis in patients with primary aldosteronism and bilateral

8 adrenal lesions. J Hum Hypertens 2015;Epub ahead of print.

9

\begin{tabular}{|c|c|c|c|}
\hline AVS Indices & Measurement & Clinical use & Cut-offs \\
\hline $\begin{array}{l}\text { Selectivity } \\
\text { index (SI) }\end{array}$ & $\begin{array}{l}\text { Cortisol }_{\text {adrenal vein }} \\
\text { Cortisol }_{\text {peripheral vein }}\end{array}$ & $\begin{array}{l}\text { Adequacy of } \\
\text { cannulation of } \\
\text { the adrenal } \\
\text { veins }\end{array}$ & $\begin{array}{l}\text { SI }>3= \\
\text { adrenal vein } \\
\text { correctly } \\
\text { cannulated }\end{array}$ \\
\hline $\begin{array}{l}\text { Lateralisation } \\
\text { index (LI) }\end{array}$ & $\begin{array}{l}\text { Aldosterone/Cortisol adrenal vein } \\
\text { Aldosterone/Cortisol } \text { contralateral }_{\text {adrenal vein }}\end{array}$ & $\begin{array}{l}\text { Differentiate } \\
\text { unitateral from } \\
\text { bilateral PA }\end{array}$ & $\begin{array}{l}\mathrm{LI}>4= \\
\text { unilateral PA } \\
\mathrm{LI}<3= \\
\text { bilateral PA }\end{array}$ \\
\hline $\begin{array}{l}\text { Contra-lateral } \\
\text { ratio (CLR) }\end{array}$ & $\begin{array}{l}\text { Aldosterone/Cortisol } \text { nondominant }_{\text {adrenal vein }} \\
\text { Aldosterone/ Cortisol peripheral } \\
\text { vein }\end{array}$ & $\begin{array}{l}\text { Retro-inhibition } \\
\text { of aldosterone } \\
\text { secretion in the } \\
\text { non-dominant } \\
\text { adrenal gland }\end{array}$ & $\begin{array}{l}\text { CLR }<1 \text { and } \\
\text { LI between } 3 \\
\text { and } 4= \\
\text { unilateral PA }\end{array}$ \\
\hline
\end{tabular}

10

11 Table 1. Calculation and clinical use of AVS indices

\begin{tabular}{|l|l|l|l|l|}
\hline & FH-I & FH-II & FH-III & FH-IV \\
\hline Gene & $\begin{array}{l}\text { Hybrid } \\
\text { CYP11B1/B2 }\end{array}$ & $\begin{array}{l}\text { Unknown } \\
\text { Linkage at 7p22 }\end{array}$ & KCNJ5 & CACNA1H \\
\hline Transmission & AD & AD & AD & $\begin{array}{l}\text { AD } \\
\text { Incomplete } \\
\text { penetrance }\end{array}$ \\
\hline $\begin{array}{l}\text { Severity of } \\
\text { hypertension }\end{array}$ & $\begin{array}{l}\text { Normotension } \\
\text { to resistant }\end{array}$ & $\begin{array}{l}\text { Normotension } \\
\text { to resistant }\end{array}$ & $\begin{array}{l}\text { Grade II to } \\
\text { resistant } \\
\text { hypertension }\end{array}$ & $\begin{array}{l}\text { Normotension } \\
\text { to resistant }\end{array}$ \\
\hline
\end{tabular}




\begin{tabular}{|l|l|l|l|l|}
\hline $\begin{array}{l}\text { u-180xoF } \\
\text { u-180HF }\end{array}$ & Elevated & Not elevated & $\begin{array}{l}\text { Mildly to } \\
\text { extremely } \\
\text { elevated }\end{array}$ & Normal \\
\hline $\begin{array}{l}\text { Aldosterone } \\
\text { response to } \\
\text { dexamethasone }\end{array}$ & $\begin{array}{l}\text { Complete } \\
\text { suppression }\end{array}$ & $\begin{array}{l}\text { Partial } \\
\text { reduction or no } \\
\text { change }\end{array}$ & $\begin{array}{l}\text { Paradoxical } \\
\text { increase (in 1 } \\
\text { family) }\end{array}$ & $\begin{array}{l}\text { Suppression in } \\
1 \text { patient }\end{array}$ \\
\hline $\begin{array}{l}\text { Adrenal CT } \\
\text { scanning/Adrenal } \\
\text { pathology }\end{array}$ & $\begin{array}{l}\text { Normal adrenal } \\
\text { glands }\end{array}$ & BAH or APA & $\begin{array}{l}\text { Bilateral } \\
\text { hyperplasia or } \\
\text { normal } \\
\text { adrenals }\end{array}$ & $\begin{array}{l}\text { Marked zona } \\
\text { glomerulosa } \\
\text { hyperplasia (in } \\
\text { 1 patient) }\end{array}$ \\
\hline
\end{tabular}

1

2 Table 2. Familial forms of primary aldosteronism. $\mathrm{FH}-\mathrm{I}=$ Familial 3 Hyperaldosteronism type 1; FH-II = Familial Hyperaldosteronism type II; FH-III = 4 Familial Hyperaldosteronism type III; FH-IV = Familial Hyperaldosteronism type $5 \mathrm{IV} ; \mathrm{AD}=$ autosomal dominant; $\mathrm{CCBs}=$ Calcium Channel Blockers; $\mathrm{BAH}=$ Bilateral 6 Adrenal Hyperplasia; APA = Aldosterone Producing Adenoma 